\title{
ANALISIS KEAMANAN APLIKASI EMAIL BAWAAN ANDROID DAN GMAIL PADA JARINGAN NIRKABEL
}

\author{
Hamid \\ Jurusan Teknik Informatika, Fakultas Teknologi Industri, Universitas Islam Indonesia \\ Jl. Kaliurang Km. 14,5 Sleman, Yogyakarta \\ E-Mail:hamid@uii.ac.id
}

\begin{abstract}
ARP Poisoning / ARP Spoofing and sniffing will always threaten wireless network user. The rise of android-based smartphone user and internet wireless network provider, allowing smartphone users to access anything including email from anywhere they want. This paper provides an overview of comparison of security analysis between use the embedded android email application with gmail email application that is connected to wireless network, as well as providing an overview of possible attack methods. This paper also provides solutions to prevent attacks from the vulnerability found.
\end{abstract}

Keywords : ARP Poisoning, ARP Spoofing, Sniffing, Wireless Network, Email Application.

\section{LATAR BELAKANG}

Android merupakan salah satu sistem operasi yang dikembangkan untuk perangkat bergerak yang bersifat open source. Sejak dirilis pada tahun 2007 (Alliance, 2007), ponsel pintar berbasis android langsung menguasai pasar ponsel pada kuartal keempat tahun 2010 dengan penguasaan pasar sebesar 32,5\% dari total penjualan ponsel pintar di dunia (Ricknäs, 2011).
Pada kuartal ketiga tahun 2013 ponsel pintar berbasis android menguasai pasar dunia dengan penguasaan pasar sebesar 81,9 $\%$ dengan total penjualan 205.222 unit (Meulen, 2013). Di Indonesia sendiri ponsel pintar berbasis android menguasai pasar dengan penguasaan pasar sebesar $56 \%$ pada tahun 2012 (Einhorn, 2012).

\section{Smartphone Operating System Market Share in Indonesia}
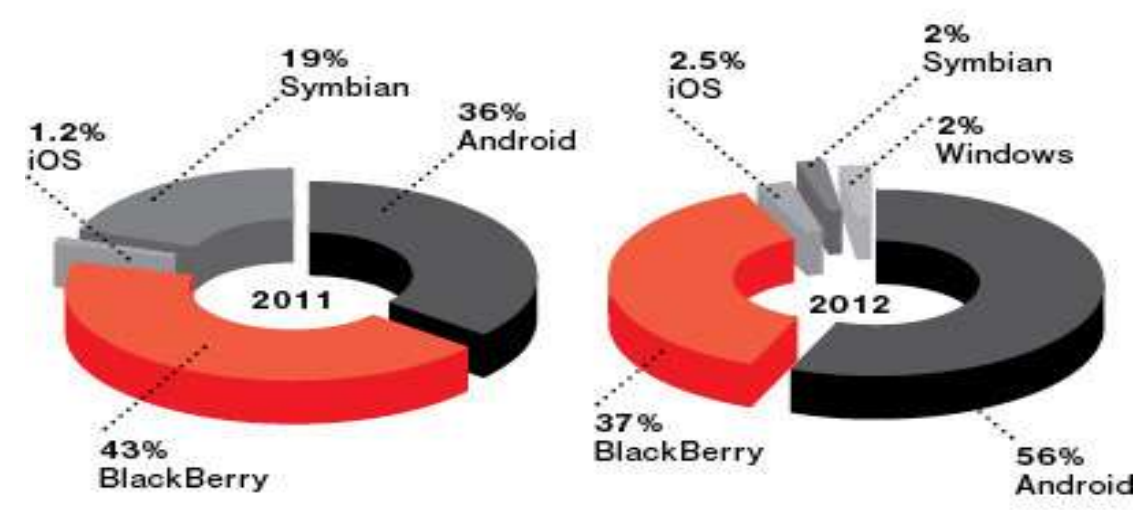

GRAPHIC BY BLOOMBERG BUSINESSWEEK. DATA: IDC

Gambar 1. Penguasaan Pasar Ponsel Pintar Berbasis Android di Indonesia.

(Einhorn, 2012) 
Ponsel pintar terutama ponsel pintar berbasis android yang semakin mampu menggantikan tugas yang sebelumnya dilakukan oleh notebook ataupun komputer personal, menghadirkan fenomena ketergantungan dan menjadikan ponsel pintar sebagai kebutuhan primer. Fitur yang sudah umum tertanam dan digunakan oleh pengguna ponsel pintar adalah fitur email. Pada ponsel berbasis android fitur email adalah fitur wajib yang ada dan sudah tertanam otomatis bersama dengan sistem operasi android itu sendiri. Selain itu pengguna sistem operasi android diwajibkan menggunakan minimal 1 (satu) akun email dari google / gmail guna mengaktifkan sistem operasi dan fitur - fitur yang ada.

Selain aplikasi email bawaan pada sistem operasi android, pengguna dapat memasang aplikasi email lain yang disediakan oleh penyedia email masing masing. Yahoo dan google merupakan contoh penyedia email yang menyediakan aplikasi email yang dapat dipasang pada ponsel android. Bagi pengguna email yang tidak menyediakan aplikasi yang berbasis android tersendiri, biasanya menggunakan aplikasi bawaan yang tertanam dalam ponsel android.

Semakin menjamurnya pengguna ponsel android maupun perangkat bergerak lain, menjadikan semakin tinggi pula kebutuhan akan internet. Internet yang cepat dan murah sangat diharapkan oleh pengguna, penyedia layanan internet juga menangkap peluang fenomena yang ada dengan memberikan banyak layanan koneksi nirkabel pada lokasi pusat keramaian. Selain penyedia jasa layanan internet, pengusaha yang membutuhkan keramaian orang juga memanfaatkan fenomena ini dengan memasang berbagai layanan internet hotspot baik gratis maupun yang berbayar.

Kemudahan berbanding terbalik dengan keamanan. Fenomena menjamurnya layanan internet hotspot menjadikan titik - titik hotspot maupun pengguna yang memanfaatkan titik tersebut menjadi target kejahatan bagi beberapa orang yang tidak bertanggung jawab.

Beberapa orang yang tidak bertanggung jawab tersebut dengan sedikit kemampuan lebih, mampu mengintip ataupun mencuri data dari pengguna layanan internet hotspot. Kemampuan yang dibutuhkan untuk melakukan kejahatan internet model seperti ini tidaklah tinggi. Bahkan sudah banyak tutorial - tutorial yang tersebar baik dalam bentuk buku maupun tutorial di internet yang dengan mudah dapat diakses oleh semua orang. Data yang diintip maupun dicuri bisa berupa username, alamat email, bahkan password.

\section{LANDASAN TEORI \\ 2.1. Email}

Email atau surat elektronik merupakan layanan pengiriman surat digital yang disediakan oleh Internet Service Provider (ISP). ISP menyediakan server email atau mail server yang berfungsi untuk melakukan pendeteksian pesan dan mengirimkannya pada email tujuan. Layanan surat elektronik sendiri terbagi kedalam dua bagian layanan surat elektronik bebas (free) dan layanan surat elektronik terbatas. Layanan surat elektronik ini sendiri dapat diakses melaui berbagai cara :

\section{Web Mail}

Merupakan aplikasi berbasis website yang disediakan oleh penyedia layanan email agar para pengguna dapat dengan mudah mengakses layanan yang diberikan. Pengguna surat elektronik hanya membutuhkan web browser serta koneksi internet untuk melakukan pengaksesan layanan tersebut.

\section{Aplikasi email Client}

Merupakan aplikasi yang dibuat khusus untuk melakukan pengaksesan layanan surat elektronik. Dengan menggunakan aplikasi mail client ini pengguna dapat dengan mudah melakukan manajemen surat elektronik yang dimiliki, bahkan dapat melakukan penulisan surat elektronik 
meskipun tidak terdapat koneksi internet (Butterfield, Tracy, \& Jansen, 2007).

Fungsi yang dilakukan oleh email client adalah sebagai berikut (EC Council, 2010) :

a. Mengambil email dari kotak surat.

b. Menampilkan header dari pesan-pesan yang ada di kotak surat. Pada beberapa kasus, sebagian isi email juga ditampilkan.

c. Menulis email baru.

Beberapa email client yang sering digunakan antara lain : Mozilla Thunderbird, Microsoft Outlook, Eudora Mail dan beberapa aplikasi email client yang terintegrasi dengan sistem operasi perangkat bergerak.

3. Email Server

Email server atau yang biasa disebut dengan mail server adalah komputer yang terhubung ke jaringan yang berfungsi sebagai kantor pos virtual, dalam hal komputer yang berfungsi sebagai penyimpan dan penyampai surat elektronik (EC Council, 2010). Proses komunikasi jaringan antara email client dan email server dapat dilihat pada gambar 2 .

Ketika email client meminta email baru ke email server, email server meminta username dan password akun email. Setelah email server mencocokkan keduanya, email server akan mengirimkan header email baru ke email client. Proses pengiriman email sendiri melalui beberapa protokol, yaitu:

1. SMTP

SMTP (Simple Mail Transfer Protocol) mekanisme yang digunakan untuk melakukan pengiriman surat elektronik antar host dalam jaringan komputer dengan menggunakan TCP / IP (Riabov \& College, 2005). SMTP merupakan protokol yang handal dan efisien yang menggunakan port 25 untuk operasinya (Jonathan B. Postel, 1982). SMTP melakukan koneksi dengan melakukan pembukaan koneksi melalui SMTP client untuk melakukan koneksi ke server SMTP, setelah server mendapatkan koneksi dari klien SMTP server akan mencari keberadaan SMTP server tujuan dan mengirimkan surat elektronik tersebut.

2. $\mathrm{POP} 3$

POP (Post Office Protocol) versi 3 merupakan protokol yang dibuat pada tahun 1984 yang berfungsi untuk melakukan penerimaan surat elektronik. POP sendiri merupakan mekanisme penarikan surat elektronik dari mail server ke aplikasi email milik pengguna. POP pada dasarnya bekerja mirip dengan kotak surat konvensional. Dengan memanfaatkan protokol POP ini surat elektronik yang berada pada mail server akan terhapus. Seperti halnya protokol email yang lain POP juga menggunakan perintah dalam operasinya (Butterfield et al., 2007). Perintah yang digunakan dapat dilihat pada gambar 3 .

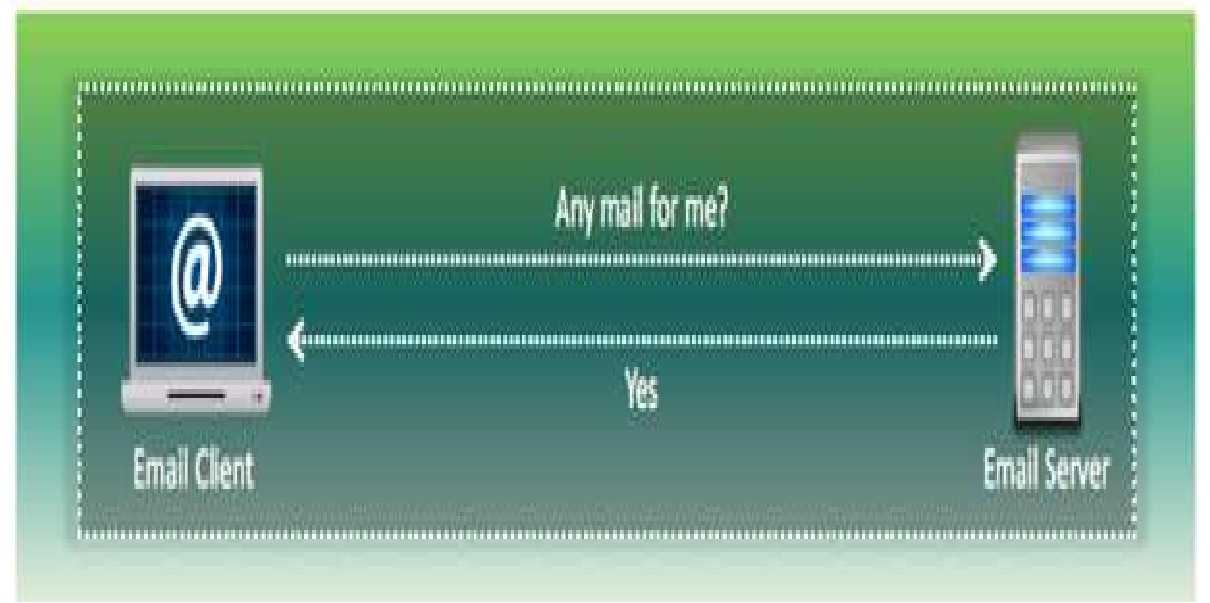

Gambar 2. Proses Komunikasi Email Client dan Email Server.

(EC Council, 2010) 


\section{IMAP}

IMAP (Internet Message Access Protocol) merupakan pengembangan dari protokol POP versi 2. IMAP memiliki fungsi yang sama dengan POP yaitu digunakan untuk melakukan pembacaan surat elektronik. Perbedaan mendasar antara POP versi 3 dan IMAP terletak pada surat yang disimpan, jika POP3 akan menyalin seluruh surat dari server dan menyimpannya pada sisi klien, IMAP tidak melakukan penyalinan dan penghapusan surat elektronik dari mail server (Butterfield et al., 2007). Perintah perintah yang dijalankan oleh protokol IMAP dapat dilihat pada gambar 4 .

\subsection{Keamanan Email}

Aspek yang penting dalam keamanan email adalah, kerahasiaan (Confidentiality), keaslian (Authentication), integritas (Integrity), anti penyangkalan (Nonrepudiation) (Stallings, 2011). Surat elektronik atau email itu sendiri bagaikan surat konvensional, jalur yang dilalui dari pengirim ke penerima sangat panjang melalui beberapa kantor pos cabang, pusat dan dibawa oleh beberapa petugas pengirim surat. Email juga demikian, jalur yang dilalui dari pengirim ke penerima melalui beberapa router, mail servers, dan beberapa jaringan komputer.

Email sangat rentan dengan serangan baik pasif maupun aktif. Contoh ancaman pasif yang mungkin adalah :

\begin{tabular}{|c|c|}
\hline \multicolumn{2}{|c|}{ Basic Commands from RFC 918} \\
\hline USER sname> & Sct usemame \\
\hline PASS 〈passworめ & Set password \\
\hline STAT & Check the status of the mailbox, typically retricies number of messages \\
\hline LIST [mse] & List mesoges in the mailbox; Optional argument for message [msg] \\
\hline RETR cmsp & Retrieve mesage Cmsg) \\
\hline DELE <ms? & Dekte message <msg \\
\hline QUIT & Quit \\
\hline NOOP & No opcration \\
\hline RSET & Reset \\
\hline \multicolumn{2}{|c|}{ Optional Commands from RFC 1939} \\
\hline TOP $\langle m s g\rangle\langle n\rangle$ & Retrieve the top $\langle\mathrm{D}>$ lines of mesage <msg \\
\hline UIDL [msk] & Retrieve unique id for [msg] \\
\hline APOP <name < <igesP & A more robust form of authentication than USERPASS \\
\hline \multicolumn{2}{|c|}{ Extension Command from RFC 2449} \\
\hline CAPA & Retrieve a list of capabilitics supported by the POP3 server \\
\hline
\end{tabular}

Gambar 3. Perintah Pada Protokol POP. (Butterfield et al., 2007)
1. Pembukaan isi email

Kebanyakan email ditransmisikan dalam bentuk jelas (tanpa enkripsi), artinya beberapa orang dengan aplikasi tertentu bisa melihat isi email.

2. Analisa lalu lintas data

Beberapa negara secara rutin memantau isi email.

Sedangkan ancaman serangan aktif antara lain sebagai berikut :

1. Modifikasi isi email

Isi email dapat dimodifikasi pada saat transportasi atau penyimpanan. Selama penyerang ada dalam satu jaringan, penyerang bisa menggunakan $A R P$ spoofing untuk mencegat lalu memodifikasi isi email ke mail server maupun dari mail server. Teknik ini yang nantinya akan digunakan untuk pengujian.

2. Masquerade (Penyamaran)

Dimungkinkan untuk mengirim pesan sebagai orang atau organisasi lain.

3. Spoofing

Pesan palsu dapat dimasukkan ke dalam sistem mail pengguna lain.

4. Denial of Service

Dimungkinkan untuk membuat mail server sibuk dan overload sehingga membuat mail server tersebut tidak bisa melayani pengguna lain (Toorani, 2008).

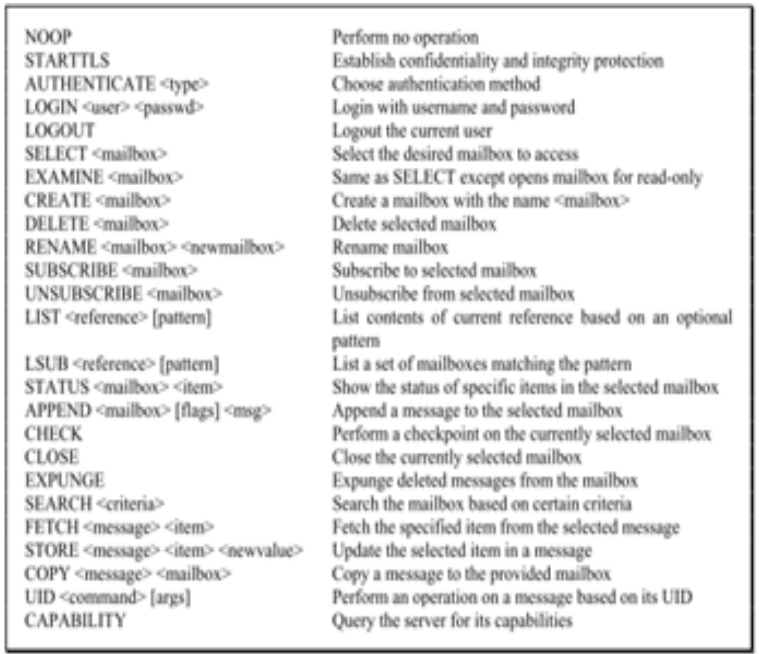

Gambar 4. Perintah Pada Protokol IMAP. (Butterfield et al., 2007) 
Guna mengatasi ancaman - ancaman tersebut diatas, maka dikembangkan metode pengamanan email yang terenkripsi. Pada dasarnya ada 2 metode dalam enkripsi email, yaitu (Stallings, 2011) :

\section{Pretty Good Privacy (PGP)}

Metode ini merupakan metode yang sangat sering digunakan. PGP dikembangkan oleh Phil Zimmerman dan dirilis pertama kali pada tahun 1991 . PGP tersedia baik gratis maupun yang berbayar. PGP mendukung enkripsi dari 5 layanan, yaitu authentication, confidentiality, compression, e-mail compatibility dan segmentation. Selain 5 layanan itu, PGP juga mendukung digital signature.

2. S/MIME (Secure / Multipurpose Internet Mail Extensions)

S/MIME dicetuskan oleh RSA Data Security pada tahun 1995. Dalam hal fungsionalitas umum, S/MIME sangat menyerupai PGP. Keduanya menawarkan kemampuan untuk menandatangai dan atau mengenkripsi pesan. Layanan - layanan yang dienkripsi juga sama dengan PGP. Pada sisi penyedia layanan, enkripsi bisa dilakukan dalam komunikasi client ke server ataupun komunikasi antar mail server. Enkripsi ini biasanya menggunakan standar enkripsi TLS (Transport Layer Security). Protokol TLS sendiri mirip dengan protokol Secure Sockets Layer (SSL) yang dikombinasikan dengan protokol POP (995), IMAP (993), dan SMTP (465) yang berfungsi untuk enkripsi komunikasi antara aplikasi email client dan email server.

\subsection{Aplikasi Email Pada Android}

Aplikasi email pada android dibagi menjadi 2 macam, yaitu :
1. Aplikasi email bawaan android Aplikasi email bawaan android ini terpasang bersama dengan sistem operasi android. Pengguna bisa memasang akun email private maupun akun email public yang disediakan oleh penyedia jasa email seperti yahoo ataupun hotmail. Hanya email dari google yang tidak dapat dipasang pada aplikasi email bawaaan ini dikarenakan aplikasi email google juga merupakan aplikasi bawaan sistem operasi android. Pada aplikasi email bawaan android ini terdapat dua macam mode pengaturan, yaitu pengaturan secara otomatis maupun pengaturan secara manual.

2. Aplikasi email dari penyedia jasa email. Aplikasi email dari penyedia jasa email biasanya disediakan oleh penyedia email public seperti yahoo ataupun google. Aplikasi email ini hanya bisa memasang email yang disediakan oleh penyedia email tersebut.

\subsection{Aplikasi Email Gmail}

Salah satu aplikasi email yang disediakan oleh google ini merupakan aplikasi email yang sangat popular digunakan oleh pengguna ponsel android. Fitur - fitur yang disediakan antara lain sebagai berikut :

1. Dapat mengatur lebih dari satu email.

2. Dapat membaca email pada saat online maupun offline.

3. Dapat membalas email saat offline lalu otomatis mengirim saat online.

4. Notifikasi yang dapat diatur.

5. Attachment dapat diihat ataupun langsung download.

Dengan beberapa fitur yang ditawarkan serta aplikasi yang bisa didapatkan dengan gratis ini maka banyak pengguna ponsel android memasang aplikasi ini pada ponselnya. 


\subsection{Komunikasi Nirkabel}

Komunikasi nirkabel adalah perpindahan data atau informasi dari dua titik atau lebih yang tidak terhubung dengan konduktor listrik. Pemancar nirkabel pertama kali mengudara diawal abad 20 menggunakan radiotelegraphy (kode morse). Semenjak itu, dimungkinkan untuk memancarkan suara, musik, video melalui jaringan nirkabel (Rouse, 2006).

Teknologi nirkabel yang paling umum digunakan adalah teknologi nirkabel elektromagnetik seperti radio. Dengan digunakannya gelombang radio, penyesuaian jarak perangkat bisa lebih fleksibel. Penggunaan gelombang radio jarak pendek bisa digunakan untuk remote control tv, remote control ac, dan beberapa perangkat nirkabel rumah tangga yang lain. Penggunaan jaringan nirkabel gelombang radio jarak jauh seperti contoh tv satelit, telepon seluler bahkan alat gps sudah banyak diterapkan saat ini.

Kelebihan penggunaan jaringan nirkabel antara lain (EC Council, 2010) :

1. Tidak perlu menarik kabel.

2. Mobilitas perangkat yang tinggi.

3. Pemeliharaan jaringan relatif lebih mudah.
4. Rancangan fleksibel (jarak pendek maupun jauh).

5. Mengikuti perkembangan jaman.

Selain kelebihan komunikasi nirkabel juga memiliki kelemahan, antara lain :

1. Isu keamanan yang masih rentan dibandingkan dengan teknologi kabel.

2. Bandwidth yang dibutuhkan lebih besar.

3. Beberapa perangkat elektronik bisa melemahkan sinyal nirkabel.

\subsection{ARP Poisoning / ARP Spoofing}

$A R P$ poisoning / ARP spoofing merupakan sebuah serangan yang menyerang transisi antara layer 3 (layer network) ke layer 2 (layer data link) dalam referensi model OSI . ARP poisoning mengubah $M A C$ address dari korban yang akan diserang. ARP poisoning juga dikenal dengan nama $A R P$ spoofing. Teknik ARP poisoning sangat efektif digunakan pada jaringan kabel maupun wireless. Tujuan serangan dari ARP poisoning ini pada umumnya adalah sniffing.

Tipe serangan ARP poisoning ini akan membuat penyerang menjadi gateway dari sebuah jaringan (EC Council, 2008). Pada saat penyerang melakukan serangan jaringan yang diserang akan menganggap penyerang adalah gateway dari jaringan tersebut.

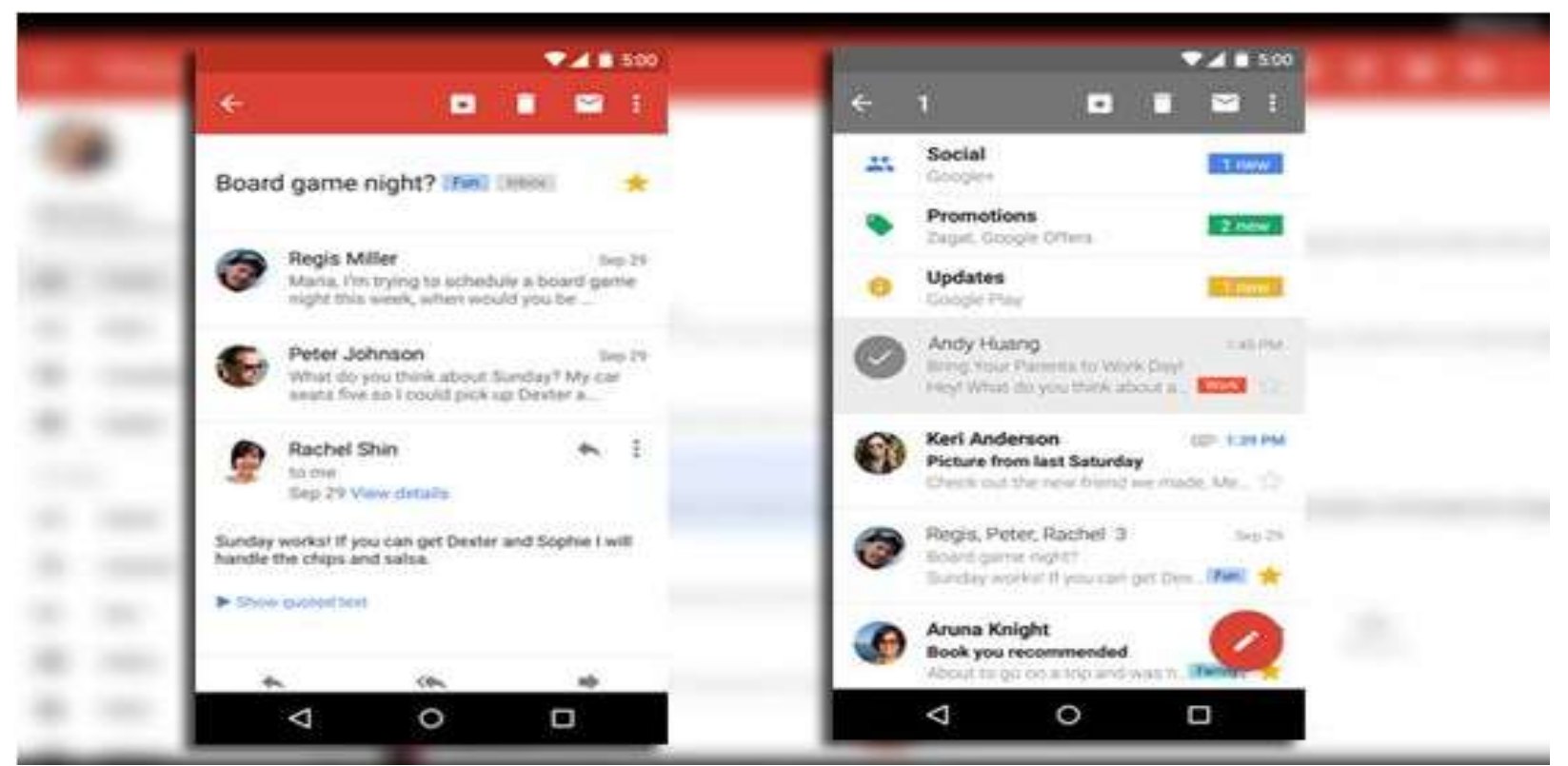

Gambar 5. Aplikasi Email Gmail Pada Ponsel Android. 
Tabel 1. Informasi Yang Dapat Diambil Dari Serangan Sniffing (ECCouncil, 2011)

\begin{tabular}{ccc}
\hline No & Protokol & Informasi yang Bisa Di dapat \\
\hline 1 & TELNET & Key Stroke \\
2 & HTTP & Data Sent in Clear Text \\
3 & SMTP & Password and Data sent in Clear Text \\
4 & NNTP & Password and Data Sent in Clear Text \\
5 & POP & Password and Data Sent in Clear Text \\
6 & FTP & Password and Data sent in Clear Text \\
7 & IMAP & Password and Data Sent in Clear Text \\
8 & SMB & Data Sent \\
\hline
\end{tabular}

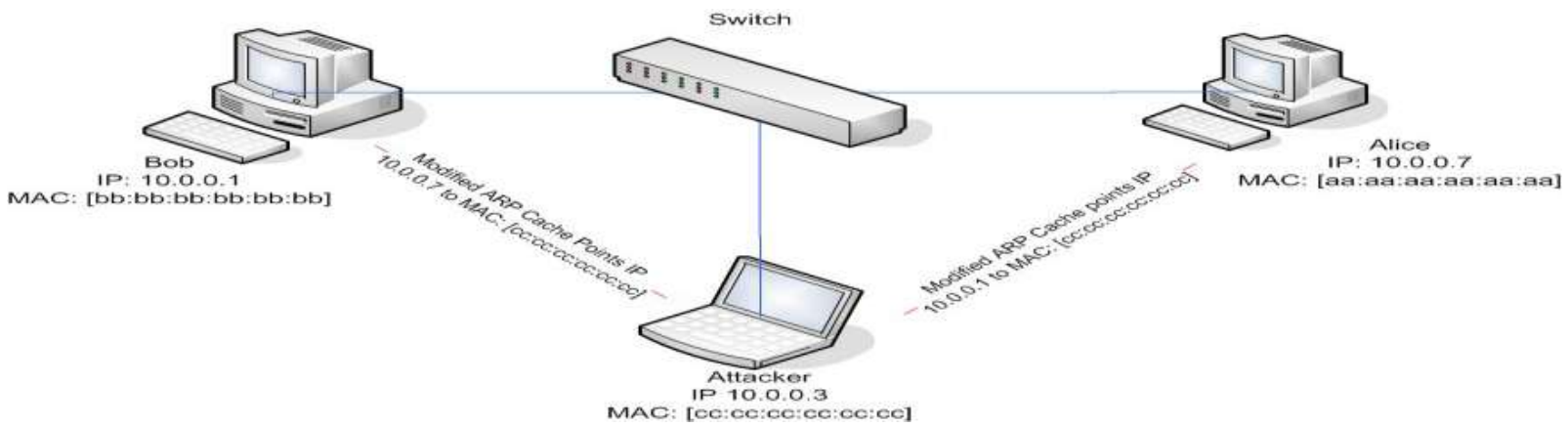

Gambar 6. Proses Terjadinya ARP Poisoning.

(EC Council, 2008)

\subsection{Sniffing}

Sniffing dalam pengertian berarti mengendus, sedangkan dalam ilmu keamanan jaringan sniffing merupakan aktifitas menangkap paket - paket data yang lewat dalam sebuah jaringan (Susanto, 2007). Sniffing sendiri biasanya digunakan untuk menangkap informasi - informasi vital dari sebuah jaringan seperti password, email text, dan File transfer. Sniffing biasanya menyerang protocol - protokol seperti Telnet, HTTP, POP, IMAP, SMB, FTP, dan lain - lain. Informasi yang didapat dari beberapa protokol di atas dapat dilihat pada tabel 1.

Dalam metode hacking, sniffing dibagi menjadi dua bagian yaitu passive sniffing dan active sniffing (Ornaghi \& Valleri, 2013).

1. Passive Sniffing

Passive sniffing merupakan aktifitas sniffing yang dilakukan pada jaringan dengan media penghubung hub. Dimana hub akan melakukan broadcast seluruh paket yang melewatinya ke seluruh node yang terhubung ke $h u b$ tersebut. Hub merupakan perangkat komputer yang melakukan broadcast paket data ke seluruh jaringan sehingga sniffing pada jaringan dengan hub sangat mudah dilakukan.

2. Active Sniffing

Active sniffing merupakan aktifitas sniffing yang dilakukan pada jaringan dengan media penghubung switch atau sejenisnya. Switch sendiri merupakan sebuah perangkat penghubung (Concentrator) yang memiliki chip untuk menyimpan tabel $M A C$ address. Switch tidak lagi mem-broadcast paket ke seluruh jaringan namun paket data yang dikirim hanya melalui port asal dan port tujuan saja. Sehingga sangat sulit untuk melakukan sniffing pada switch. Diperlukan metode khusus untuk melakukan sniffing pada switch. Untuk melakukan sniffing pada jaringan dengan switch kita perlu membuat membanjiri media penyimpanan pada switch dengan MAC address sehingga switch tersebut tidak ada bedanya dengan hub. Untuk membanjiri media penyimpanan dapat menggunakan ARP poisoning ataupun $M A C$ Flooding (Susanto, 2007). 


\section{HASIL DAN ANALISIS}

\subsection{Pengujian}

Pengujian

dilakukan

untuk membandingkan tingkat keamanan aplikasi email yang otomatis terpasang pada sistem operasi android serta aplikasi email gmail yang keduanya terhubung dengan jaringan nirkabel. Dalam pengujian ini dilakukan proses sniffing dengan digabungkan dengan teknik ARP spoofing / poisoning. Skema pengujian dapat dilihat pada gambar 7 .

Melakukan ARP spoofing atau ARP poisoning merupakan suatu kewajiban dalam tujuan untuk melakukan active sniffing. ARP poisoning dilakukan pada jaringan yang dipasang untuk skenario pengujian yaitu jaringan dengan akses poin yang difungsikan sekaligus sebagai gateway router.

Pengujian pada penelitian ini terdiri dari 3 (tiga) skenario pengujian sebagai berikut :
1. Pengujian pada aplikasi email bawaan dengan menggunaan protokol POP (Post Office Protocol).

2. Pengujian pada aplikasi email bawaan dengan menggunakan protokol IMAP (Internet Message Access Protocol).

3. Pengujian pada aplikasi email gmail.

Aplikasi ettercap digunakan untuk melakukan proses ARP Poisoning. Ettercap merupakan tool yang dibangun untuk melakukan proses sniffing pada jaringan (Ornaghi \& Valleri, 2013).

Meskipun aplikasi ettercap dapat melakukan ARP poisoning sekaligus sniffing, namun aplikasi wireshark digunakan dalam melakukan proses sniffing. Wireshark sendiri merupakan aplikasi yang digunakan aplikasi yang dapat digunakan untuk melakukan sniffing sekaligus analisa hasilnya (Wireshark, 2013).

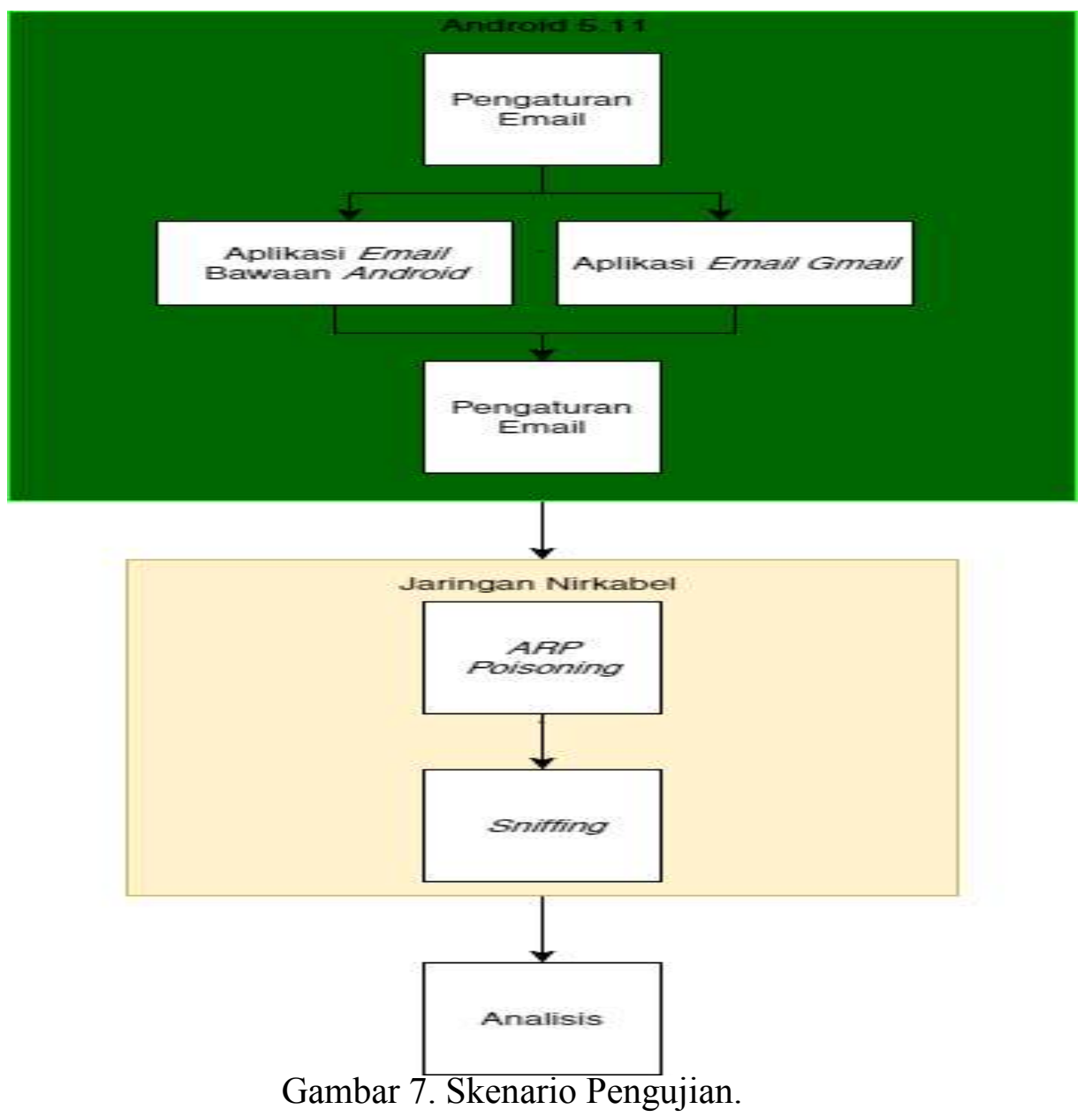


Tabel 2. Hasil Pengujian Protokol Email

\begin{tabular}{c|c}
\hline PROTOKOL & DATA OTENTIKASI \\
\hline POP & CLEAR TEXT \\
IMAP & $C L E A R T E X T$ \\
POP TLS & ENCRYPTED \\
IMAP TLS & ENCRYPTED \\
\hline
\end{tabular}

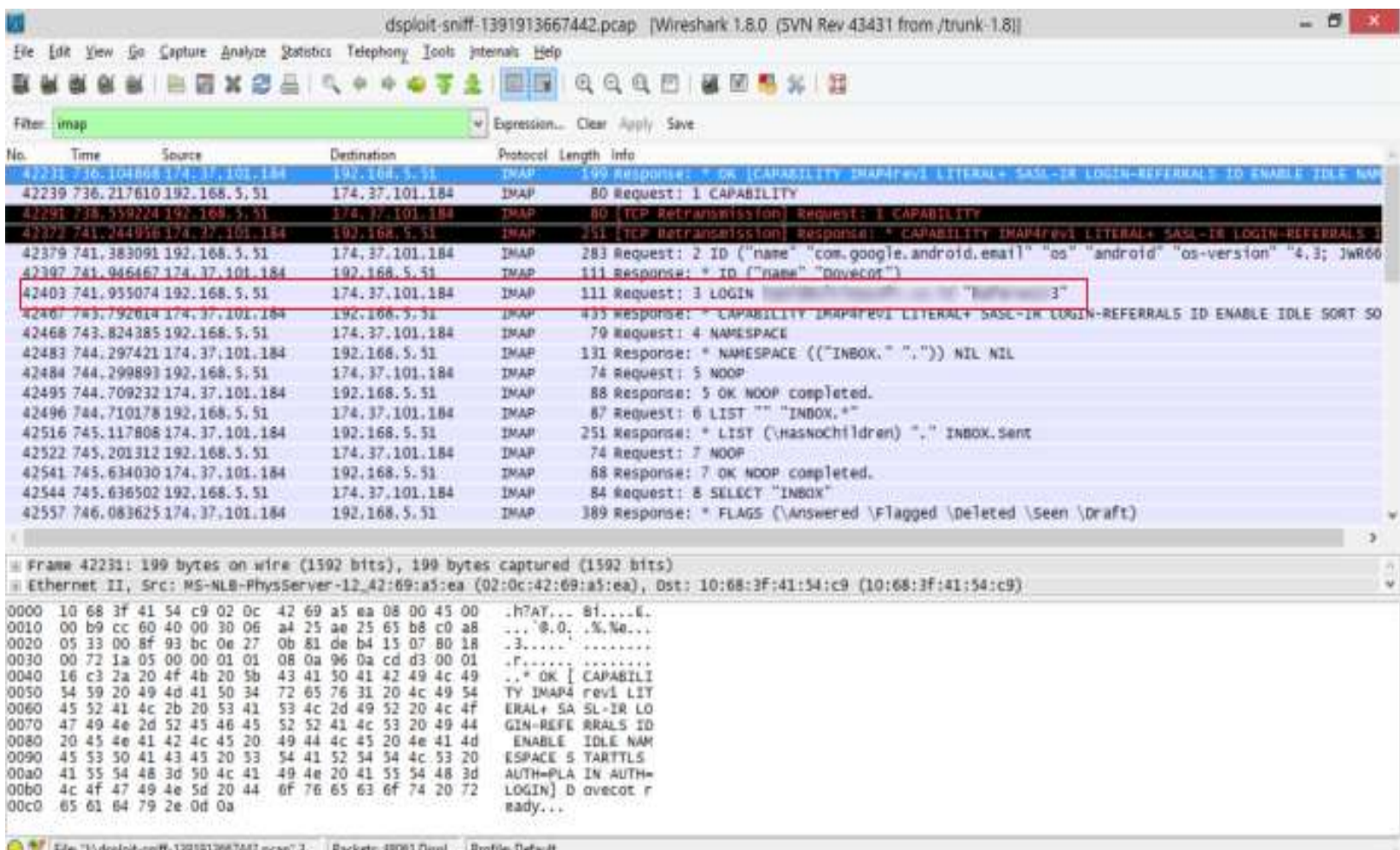

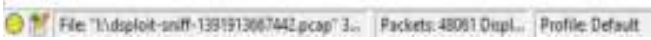

Gambar 8. Komunikasi Data Aplikasi Email Bawaan Android Protokol IMAP.

File Édit View Go Capture Analyze Statistics Telephony Wireless Iools Help

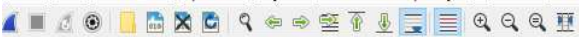

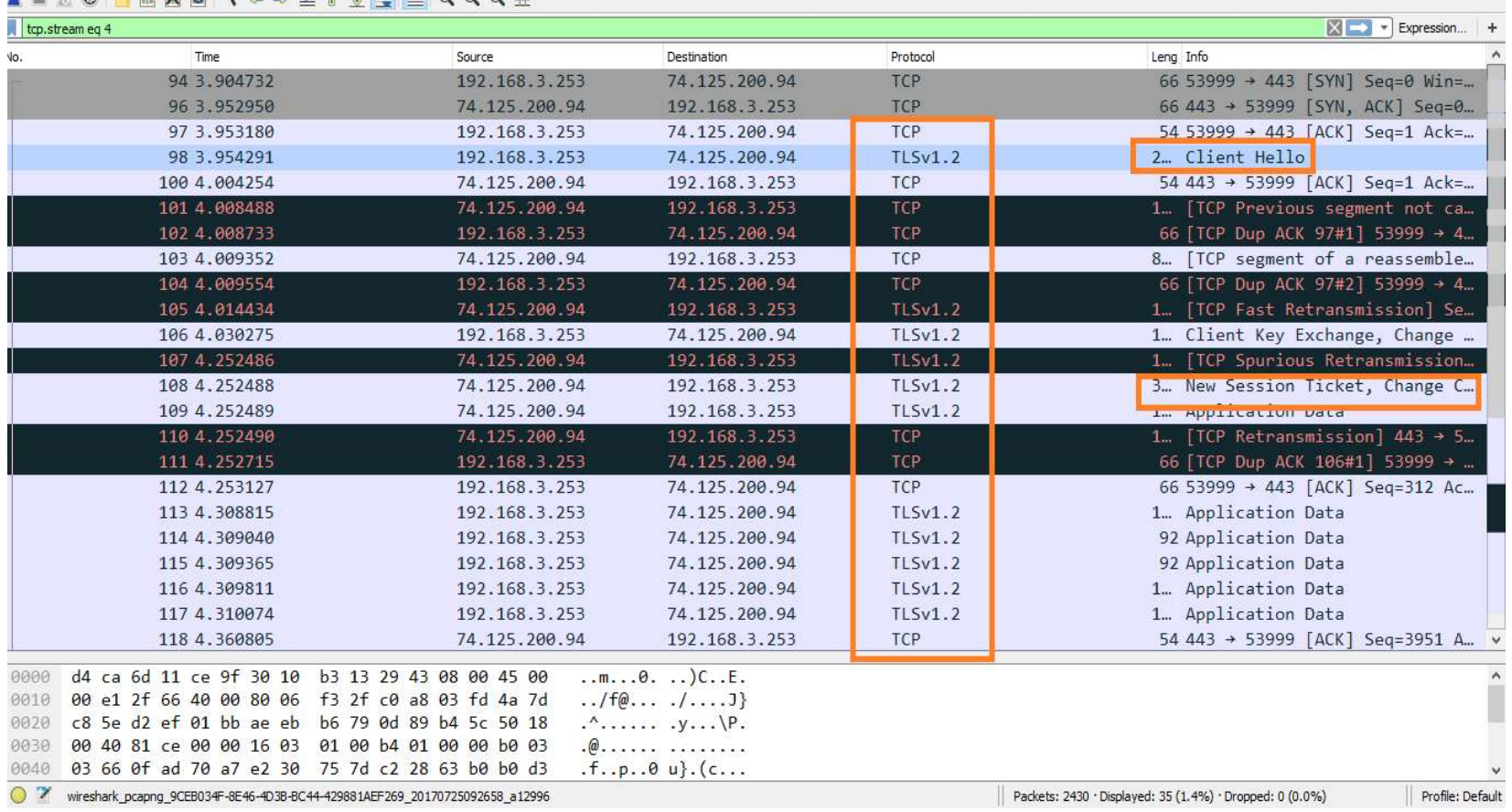

Gambar 9. Komunikasi Data Aplikasi Email Gmail. 
Setelah ARP poisoning berhasil dilakukan, komunikasi datang pengguna yang menggunakan jaringan nirkabel yang sama akan terekam. Contoh hasil sniffing dapat dilihat pada gambar 8 .

Gambar diatas menampilkan komunikasi data aplikasi email bawaan dengan menggunakan protokol IMAP. Gambar tersebut memperlihatkan bahwa pengujian ke-2 menghasilkan komunikasi data dengan username dan password dapat dibaca dalam bentuk cleartext tanpa enkripsi apapun. Komunikasi data tersebut juga menunjukkan bahwa proses login dan listing email berhasil.

1. Pengujian pada aplikasi email gmail.

Hasil sniffing pada aplikasi email gmail dapat dilihat pada gambar 9. Terlihat pada gambar bahwa proses login email di enkripsi, yang terlihat hanya informasi bahwa proses login berhasil.

Dari hasil uji yang dilakukan pada 3 (tiga) skenario dengan langkah - langkah sebelumnya maka didapat hasil pada tabulasi pengujian. Hasil tabulasi dapat dilihat pada Tabel 2.

\subsection{Analisis Hasil Uji}

Pengujian dengan 3 (tiga) skenario telah dijalankan lalu pengujian serta analisa dilakukan lebih lanjut dengan hasil sebagai berikut :

1. Komunikasi data pada pengujian aplikasi email bawaan dengan menggunakan opsi protokol POP menunjukkan bahwa username dan password dapat dilihat secara cleartext. Pengujian juga dilakukan dengan menunjukkan proses memasukan username dan password yang benar sehingga login berhasil dengan username dan password tersebut. Hal ini juga berarti bahwa username dan password yang terekam juga dapat dibuktikan kebenarannya.
2. Komunikasi data pada pengujian aplikasi email bawaan dengan menggunakan opsi protokol IMAP menunjukkan bahwa username dan password dapat diilihat secara cleartext. Pengujian juga dilakukan dengan menunjukkan proses memasukan username dan password yang benar sehingga login berhasil dengan username dan password tersebut. Hal ini juga berarti bahwa username dan password yang terekam juga dapat dibuktikan kebenarannya.

3. Komunikasi data pada pengujian aplikasi email gmail menghasilkan username dan password yang terenskripsi. Komunikasi data yang dapat dilihat hanya proses login ke server serta proses login berhasil.

Pada pengujian ke-1 dan pengujian ke-2 digunakan 2 (dua) private email, sedangkan pada pengujian ke-3 digunakan google mail. Dari pengujian tersebut juga ditemukan bahwa :

1. Dua private email yang digunakan untuk pengujian mendukung penggunaan protokol POP dan IMAP.

2. Dua private email yang digunakan untuk pengujian tidak mendukung protokol POP dengan security dan IMAP dengan security (untuk pengaturan lebih lanjut).

3. Google mail pada pengujian (3) tidak perlu melakukan konfigurasi lebih lanjut dan otomatis menggunakan protokol TLS.

Walaupun aplikasi email gmail tidak dapat dilihat datanya, namun hal ini paling tidak membuktikan bahwa serangan ARP poisoning / spoofing sangat mungkin dilakukan pada jaringan nirkabel. 


\section{KESIMPULAN}

Setelah dilakukan pengujian dan analisis dapat ditarik beberapa kesimpulan, sebagai berikut :

1. Salah satu serangan yang harus diwaspadai dalam jaringan nirkabel adalah serangan ARP spoofing / poisoning. Serangan ini bisa digunakan untuk mendukung serangan lain seperti sniffing.

2. Secara default saat melakukan konfigurasi aplikasi email bawaan android secara otomatis akun email menggunakan protokol POP ataupun IMAP sesuai dengan penyedia. Konfigurasi otomatis ini tanpa pengaturan security (TLS).

3. Pengaturan konfigurasi aplikasi email bawaan android secara default ataupun otomatis mengakibatkan username dan password dapat dibaca secara cleartext.

4. TLS sudah dipublikasikan sebagai kesepakatan internet protokol pada tahun 1999 (Chandrataruna \& Ngazis, 2013), namun masih banyak private email tidak menyertakan protokol TLS untuk tambahan keamanan pada protokol POP dan IMAP. Ini terjadi dikarenakan mahalnya infrastruktur maupun investasi yang harus disediakan untuk pengadaaan protokol TLS ini. Google sendiri mulai menggunakan protokol TLS pada POP dan IMAP pada tahun 2004, dan menggunakan TLS pada SMTP pada tahun 2011 (Chandrataruna \& Ngazis, 2013).

5. Pencegahan untuk menghindari penyadapan data email dapat dilakukan dengan cara sebagai berikut :

a. Melakukan konfigurasi advanced / lanjut apabila menggunakan aplikasi email bawaan android sehingga dapat menambahkan protokol TLS. Hal ini tentu saja dapat dilakukan dengan catatan server private email tersebut mendukung protokol keamanan TLS. b. Untuk private email yang tidak menyediakan ataupun mendukung protokol keamanan TLS, bisa dipertimbangkan 2 (dua) alternatif berikut :

- Menggunakan fitur forwarding email google, yang merupakan satu - satunya penyedia layanan email yang menggunakan protokol TLS pada penerimaan maupun pengiriman email (Chandrataruna \& Ngazis, 2013).

- Menggunakan aplikasi email gmail untuk private email. Gmail mendukung penggunaan akun email selain akun gmail itu sendiri untuk ditambahkan dalam aplikasi email gmail.

Standard operating procedure (SOP) juga diperlukan dalam mengantisipasi serangan ARP spoofing / poisoning ini. SOP ini berlaku baik untuk pengguna ataupun penyedia layanan jaringan nirkabel. Antara lain sebagai berikut :

1. Bagi pengguna layanan jaringan nirkabel, sebagai berikut :

a. Tidak sembarangan membuka koneksi ke jaringan nirkabel yang belum dikenal.

b. Memastikan anti virus ataupun firewall selalu dalam pembaruan terbaru.

2. Bagi penyedia layanan jaringan nirkabel, sebagai berikut :

a. Pemasangan router atau akses poin yang mendukung anti ARP spoofing / poisoning.

b. Menindak pelaku kejahatan komputer dalam wewenang jaringan penyedia.

c. Update berkala firmware akses poin ataupun router. 


\section{DAFTAR PUSTAKA}

Alliance, O. H., 2007. Industry Leaders Announce Open Platform for Mobile Devices. Retrieved January 02, 2014, from http://www.openhandsetalliance.co m/press_110507.html.

Butterfield, J., Tracy, M., \& Jansen, W., 2007. Guidelines on Electronic Mail Security Recommendations of the National Institute of Standards and Technology.

Chandrataruna, M., \& Ngazis, A. N., 2013. Mengapa Badan Keamanan AS Bisa Sadap E-mail? Retrieved March 01, 2014, from http://m.news.viva.co.id/news/read/ 423514-mengapa-badankeamanan-as-bisa-sadap-e-mail.

EC Council., 2008. Ethical Hacking and Countermeasures Module XIII Hacking Email Accounts News.

EC Council., 2010a. CHFI v8 Module 17 Investigating Wireless Attacks.pdf.

EC Council., 2010b. CHFI v8 Module 19 Tracking Emails and Investigating Email Crimes.pdf.

EC Council., 2011. CHFI v8 Module 17 Investigating Wireless Attacks.pdf. ECCouncil.

Einhorn, B., 2012. Indonesians Still Love Their BlackBerrys - Businessweek. Retrieved January 04, 2014, from http://www.businessweek.com/articl es/2012-12-06/indonesians-stilllove-their-blackberrys.

Jonathan B. Postel., 1982. SIMPLE MAIL TRANSFER PROTOCOL. RFC, 90291(August).

Meulen, R. van der., 2013. Gartner Says Smartphone Sales Accounted for 55 Percent of Overall Mobile Phone Sales in Third Quarter of 2013. Retrieved January 03, 2014, from http://www.gartner.com/newsroom/i $d / 2623415$.
Ornaghi, A., \& Valleri, M., 2013. Ettercap. Retrieved March 23, 2013, from http://ettercap.github.io/ettercap/.

Riabov, V. V, \& College, R., 2005. SMTP ( Simple Mail Transfer Protocol).

Ricknäs, M., 2011. Android Becomes Best selling Smartphone OS, Says Canalys PC World. Retrieved January 04, 2014, from http ://www.pcworld.com/article/218219 landroid becomes best selling sm artphone_os_says_canalys.html.

Rouse, M., 2006. Definition of Wireless. Retrieved March 27, 2013, from http://www.techtarget.com/.

Stallings, W., 2011. Network Security Essentials: Applications And Standards (4th ed.).

Susanto., 2007. Seni Teknik Hacking 2 (Edisi Dua.). Jakarta: Jasakom.

Toorani, M., 2008. SMEmail - A New Protocol for the Secure E-mail in Mobile Environments. 2008 Australasian Telecommunication Networks and Applications Conference, 39-44. doi:10.1109 / ATNAC. 2008. 4783292. 